\title{
KLAUS HOLZKAMP AND THE RISE AND DECLINE OF GERMAN CRITICAL PSYCHOLOGY
}

\author{
Thomas Teo \\ York University
}

\begin{abstract}
This history of German Critical Psychology focuses on the works of its most significant representative, Klaus Holzkamp (1927-1995), and reconstructs the development of his ideas, critiques, and results. For historical-systematic reasons his work is divided into a precritical period (until 1968), a critical-emancipatory period (1968-1972), a critical-conceptual period (1973-1983), and a subject-scientific period (1984-1995). Social movements and internal problems of traditional psychology are identified as factors in the rise of his psychology, whereas the decline of Critical Psychology in the 1980s and 1990s is attributed to social developments, limitations of a systematic-foundational framework, and the emergence of alternative critical approaches. Despite these problems the article shows that Holzkamp is an eminent theoretical psychologist who has made significant contributions to psychological knowledge.
\end{abstract}

North American books on the history of psychology (e.g., Fancher, 1996) acknowledge widely the contributions of German psychology but usually recognize pioneers and approaches only before 1933 . This emphasis has legitimacy on one side but certainly represents a shortcoming on the other: It is correct that after 1945 an Americanization of West German psychology (Métraux, 1985) left German mainstream psychology without an internationally established German identity. But even after 1945 genuine German approaches were emerging that deserve international recognition. One of the most substantial approaches is German Critical Psychology (CP), known mostly for its founder and promoter, Klaus Holzkamp (1927-1995), a significant figure in postwar German psychology and one whose monographs inaugurated heated discussions in the psychological community. ${ }^{1}$ To understand the nature of his critical-psychological framework, which differs substantially from North American mainstream psychological thought and methodology, it is necessary to identify, from a synchronic point of view, general characteristics of $\mathrm{CP}$.

CP represents a system model of psychology. CP's notion of a foundation of psychology (Holzkamp, 1983) originates from an 18th- and 19th-century concept of science that has been criticized by research-oriented scientists and, more recently, by postmodern philosophers and sociologists of knowledge. Holzkamp personifies the German conceptual, foundational, and systematic tradition, as do Kant, Hegel, and Marx. Staeuble (1985) distinguished the two approaches to

I appreciate the helpful comments of Angela Febbraro.

Correspondence concerning this article should be addressed to Thomas Tea, Department of Psychology, Faculty of Arts, York University, 4700 Keele Street, Toronto, Ontario, Canada M3J IP3. Electronic mail may be sent to tteo@yorku.ca.

'A complete list of Holzkamp's works can be found in the Journal Forum Kritische Psychologie, Vol. 36, pp. 180-193. The list is based on Jaeger and Osterkamp (1987). 
psychology when she referred to a research model of science and a system model of science (p. 32). The system model of science in psychology, plagued by the successes of the research model since the middle of the 19th century, seeks to capture the totality of a reality through a coherent, rigorous, and organized system of basic concepts.

$\mathrm{CP}$ acts within a utopian tradition of psychology. Within this framework (cf. Morawski, 1982), for which a reactionary (e.g., eugenics) and a progressive movement may be distinguished, psychological issues are linked to societal goals. More specifically, $\mathrm{CP}$ is conceived as part of the Marxist research program, with the ultimate goal of a class-free society in which everyone can live according to his or her abilities and needs and in which relationships among individuals are not determined by market relations. Within Marxist disciplines, $\mathrm{CP}$ represents a dialecticalmaterialist science of the subject or individual: a Marxist psychology. This utopian dimension made CP a very attractive social commodity-at least for a certain time.

$\mathrm{CP}$ evolved in the context of radical political and social movements. In the context of the late 1960s and 1970s, several critical approaches in German psychology emerged. Thus, the term critical psychology is ambiguous in Germany. The (West) Berlin group that formed around Klaus Holzkamp is known as uppercase Critical Psychology (CP). A second critical psychology is organized more or less around the journal Psychologie und Gesellschaftskritik (Psychology and Critique of Society) and is referred to as lowercase critical psychology (cp). The latter does not share CP's goal of an alternative comprehensive foundation of psychology (Rexilius, 1987) and thus has developed no distinct system of research. Rather it refers to politically interested individuals who share the critique of and discontent with mainstream psychology while understanding psychology as a societal science (Rexilius \& Mattes, 1988). Freudian Marxism, a type of critical psychology that was inspired by works of the Frankfurt school and that attempted to combine Marxism and psychoanalysis, has been marginalized; its impact on German psychology still remains to be investigated. Critical 'historians of psychology who may be labeled critical psychologists perform critical research, while at the same time they do not have to compete with traditional psychology for better theories and methods. Critical approaches in psychology that include feminism or multiculturalism as basic ideas are not yet sufficiently developed in Germany to constitute recognizable and accepted academic research programs.

$\mathrm{CP}$ as a research program is the outcome of a community. The usual focus on Holzkamp as the mastermind of $\mathrm{CP}$, as the prolific and substantial writer of $\mathrm{CP}$, as the founder of $\mathrm{CP}$, as the (former) editor of the journal Forum Kritische Psychologie [Forum Critical Psychology], as the significant figure at the center of CP (the Psychological Institute of the Free University of Berlin), or as the political target in the public sphere of Germany, neglects the major impact of an interdisciplinary working group that built CP collaboratively.

CP, and especially Holzkamp, were not interested in tapping into a North American market for psychology. Only a few works of Holzkamp and other critical psychologists, and none of Holzkamp's monographs, have been translated into English (see Tolman, 1994). Thus, he is not well known and read in North America. This differentiates Holzkamp, for example, from the internationally recognized German social philosopher Jürgen Habermas, most of whose books have been translated into English (see Teo, 1995). 


\section{Focus of the Reconstruction}

A comprehensive history of German $\mathrm{CP}$ is beyond the scope of this article, and important aspects of this history have been analyzed by several authors (Maiers, 1991; Tolman, 1989, 1994; Tolman \& Maiers, 1991; van Ijzendoorn \& van der Veer, 1984) ${ }^{2}$ This short history focuses on the turns of CP as represented in the works of Klaus Holzkamp and analyzes these turns in terms of internal as well as external conditions. The decline of $\mathrm{CP}$ is specifically linked to the problem of $\mathrm{CP}$ as a system of categories and to the social dimension of $\mathrm{CP}^{3}$

In this reconstruction several idealizations have been made. The focus on the works of Holzkamp is a limitation and neglects a number of factors, including the contributions of other critical psychologists, the group dynamics within CP (which would require exhaustive interviews with representatives), institutional constraints and possibilities, discussions between diverse critical psychologists, the discourse within Marxism, and the broader culture of Germany. Yet a focus on Holzkamp is not intended to simplify the analysis to the point of arguing that the decline of $\mathrm{CP}$ corresponds directly to the death of one of its most significant representatives (cf. Kuhn, 1962). Still, the focus on Holzkamp is not arbitrary. The sophisticated research program of $\mathrm{CP}$ would not have been possible without the works of many individuals, but $\mathrm{CP}$ as it stands is not imaginable without the contributions of Holzkamp. It is indeed the writings of Holzkamp in which major arguments, concepts, and discussions of CP have been crystallized.

Holzkamp's work may be divided for historical-systematic reasons into four phases. The precritical period began with his first writings and lasted until 1968, the year in which he published the monograph on Science as Action (Holzkamp, 1968) but in which he also wrote his first critical-theoretical articles. The critical-emancipatory period lasted from 1968 to 1972, the year in which he published Critical Psychology: Preparatory Works (Holzkamp, 1972b). The critical-conceptual period lasted from 1973 to 1983, from the publication of Sensory Knowledge (Holzkamp, 1973) to Foundation of Psychology ${ }^{4}$ (Holzkamp, 1983). Since 1984 and until his death in 1995 we can talk about a subject-scientific period of CP (a psychology from the standpoint of the subject).

\section{Precritical Period}

The precritical period (until 1968) may be labeled as precritical only from the perspective of Holzkamp's later writings, as his early writings were already critical of traditional methodology. Holzkamp attempted to solve the problems of traditional psychology within the logic of reflection and change within traditional psychological research. He attributed the central weaknesses of psychology to a wrong philosophy of science. Consequently, he tried to develop a new philosophy of science, called constructivism, in which new criteria for research were developed (Holzkamp, 1968).

\footnotetext{
${ }^{2}$ Histories of CP have been written in German by Holzkamp (1988) himself, Maiers and Markard (1987), and Teo (1993).

${ }^{3}$ This focus allows me to draw conclusions for the further development of critical thinking in psychology (see Teo, in press).

${ }^{4}$ The title Grundlegung der Psychologie is translated in this article as Foundation of Psychology. Tolman (1989) translated it as Laying the Foundation for Psychology. Another possible translation: Groundwork of Psychology.
} 
In 1964 he published Theory and Experiment in Psychology (Holzkamp, 1964), about which Wolfgang Köhler wrote in a letter to Holzkamp in 1965: "It seems to me to represent a unique achievement in this field of study" (as cited in Keiler, 1987, p. 124). ${ }^{5}$ In this treatise he investigated the relationship between theory and experiment and demonstrated convincingly that the interpretation of experimental results is not binding and that psychology offers theories for which one can produce experiments that both verify or falsify the theory, always according to one's needs. It is worthwhile to mention that Holzkamp performed experiments himself (e.g., Holzkamp \& Keiler, 1967) while discussing problems with the psychological experiment.

During that time he did not challenge the basic value of experiments for psychology, and he argued that doubts about experiments are due to misunderstandings (Holzkamp, 1964). As a remedy for such problems, he suggested a variety of criteria that should guide researchers as they strive to achieve representative experiments for their theories. Only later, during the critical-conceptual period, did Holzkamp (1981) clearly distance himself from this project, arguing that nobody cares about such criteria and that even he himself did not care about them in his experiments (p. 277).

Four years after the publication of Theory and Experiment in Psychology Holzkamp published the book Science as Action (Holzkamp, 1968), a work that was intended for the scientific community as an alternative to the traditional philosophies of science. He sought to demonstrate that the empirical-inductive philosophy of science was untenable, and he attempted to develop a philosophy of science that would do justice to the authentic scientific activities of researchers. From the perspective of hindsight, and in light of the attention that the social constructionist movement in psychology has received in the 1980s and early 1990 s, his ideas, including the notion that reality is constructed and created in psychological experiments, seem highly contemporary once again.

During this precritical period, Holzkamp $(1964,1968)$ did not refer explicitly to a social utopia, although he believed that his books might contribute to a better and sounder psychology. Furthermore, he did not develop a system of categories at this point, although his foundational intentions are reflected in the subtitle of the epistemological monograph (Holzkamp, 1968): Essay on a New Foundation of the Philosophy of Science.

\section{Critical-Emancipatory Period}

The emergence of critical psychologies in Germany must be understood within the context of a broader social development in modern industrialized societies in the 1960s (Teo, 1993). As is well known, social movements challenged the status quo by criticizing traditional structures and procedures in society, culture, politics, and academia. Social issues, social explanations, and social sciences promised a solution for many problems and were on the ascendance in the intellectual arena. ${ }^{6}$

Additionally, critical psychologies in Germany must be understood in the

${ }^{5}$ This quotation and all following quotations for which no translations could be found have been translated by me.

${ }^{6}$ Nevertheless, one should not forget that biological explanations for social phenomena were influential during this time, too. 
context of postwar West Germany and the specific social-cultural problems of this society (Benz, 1989). The Cold War; authoritarian structures in all arenas of life, and especially in universities; the perceived failure of the majority of the population to deal adequately with Germany's past; and a lack of knowledge about parental involvement in Nazism, covered up by economic growth, sensitized many students to challenge overarching assumptions and established behaviors within society (Teo, 1993). The Free University of Berlin became a center for alternative agendas (Rabehl, 1988). For example, in 1967 students founded at the Free University of Berlin a Critical University that sought the permanent critique of universities and the preparation of its students for political practice, based on scientific knowledge.

The German student movement in its diverse developments (Teo, 1993) had a direct influence on the thinking of Holzkamp, who was already recognized as a leading theoretical psychologist in Germany when the ideas of the student movement became predominant in his thinking. ${ }^{7}$ This context must be taken into account if one wishes to understand why he sought to develop a "better" psychology, and not just criticize psychology, as many psychology students did. Lowercase critical psychologists were emerging mainly from the student movement itself, challenging the psychological mainstream or even wishing to abolish psychology as such (see Teo, 1993).

The need for challenge was motivated not only by psychology's limited theories but also by the actual experience that psychology, and especially its methodology, did not address the burning issues of the time (Mattes, 1985). All critical psychologists drew on Marx, but there was no common agreement about which aspects of his thought should be incorporated into their theories. Critical psychologists also held differing views of the socialist countries, particularly the German Democratic Republic. After the Berlin group adopted its socialist stand, it tended to show more sympathy for the German Democratic Republic than did others.

In this transitional critical-emancipatory period (1968-1972), Holzkamp attempted to formulate a solution to problems in psychology by finding a compromise between critical-theoretical reflection and traditional psychology, a middle ground that was intended to lead to an emancipatory psychology. After incorporating topics of the student movement and critical theory, he published the book Critical Psychology: Preparatory Works (Holzkamp, 1972b), in which he reprinted those journal articles that were celebrated by all critical--psychological movements in Germany and outlined key issues of an emancipatory psychology. During this period, to be critical meant for Holzkamp: (a) to question the relevance of psychology for practice; (b) to identify problems of traditional psychological methodology; and (c) to disclose psychology's hidden, ideological assumptions.

${ }^{7}$ The psychologically interesting question of why Holzkamp was influenced by the student movement whereas other professors were not is difficult to answer. From a problem-oriented point of view one could argue that ideas from the student movement were applicable to Holzkamp's goal of a better psychology. From an institutional perspective one could show how a group dynamic may have influenced Holzkamp's behavior, but it would not explain why Holzkamp assimilated and accommodated these ideas. One could also reflect on Holzkamp's personality or argue that it was his free choice in a given meaningful context. Nevertheless, there will probably be no completely sufficient answer to this question. 
In 1968 Holzkamp (1970/1972e) completed a text on the relevance of psychology for practice. He argued that the sophistication of experimental methodology and inferential statistics had led to the particularization and reduction of reality in psychological research. Yet the world of the psychologist in practice consists of problems of individuals in social contexts. In real life settings, all variables that had been controlled or excluded in the laboratory show effects. Thus, he argued, psychology cannot achieve technical relevance. Moreover, technical relevance alone would imply working for the powerful in society if it were not tied to emancipatory relevance, which is accomplished when research helps individuals to obtain self-enlightenment about their societal and social dependencies.

In the same article Holzkamp (1970/1972e) argued that a basic difference exists between the subject matter of physics and psychology. From an ontic point of view, research in physics can be characterized in terms of a subject-object relationship, whereas empirical research in psychology can be understood only in terms of a subject-subject relationship. The argument was repeated and developed in an article completed in 1969 in which Holzkamp (1972c) revealed that the experiment depends on the acceptance of prearranged, reversible roles: The experimenter assumes implicitly that the research subject demonstrates the role of a subject in an experiment and thus displays only limited behavior. However, if the experiment depends on a cooperative subject, then the conceptualization of psychology as a natural science, as a nomothetic science, is misleading.

Holzkamp (1970/1972d) did not argue that the problems of traditional psychology were arbitrary but rather that they constituted ideological influences on psychology that reflected the sociohistorical context in which it exists. According to his analysis, traditional psychology conceptualizes the individual as concrete, whereas concepts such as society are perceived as abstractions. He argued that this idea results from the bourgeois ideology of the individual. From a Marxist perspective, however, the notion of the individual is not at all concrete but is extremely abstract, especially as long as traditional psychology abstracts the individual from her or his historical-societal position.

Holzkamp urged, in responding to the weaknesses of traditional psychology, for psychological enlightenment in binding theory to practice, for a free and symmetric dialogue within research purged of power, and for the development of a socially responsible psychology. This critical-emancipatory psychology remained programmatic but was soon overtaken by a new critical psychology inspired by the socialist turn of the German student movement (Teo, 1993). At the end of the book Critical Psychology: Preparatory Works, Holzkamp (1972a) included a selfcritical evaluation of his own articles, indicating his socialist turn, which moved him away from neo-Marxism and toward classical Marxism.

To understand Holzkamp's shift from critical-emancipatory psychology to critical-conceptual psychology, it is important to mention the development of the student movement, the changes at the Psychological Institute at the Free University of Berlin (Mattes, 1988), and his experiences with a "scandal" (Teo, 1993). Parts of the student movement became more radical, it was argued that the academic critical-theoretical approach had major deficiencies with respect to political-practical tasks, and it was implied that social change must be initiated by the working class.

In the context of university reforms that led to a more democratic governance 
of German universities, the Psychological Institute at the Free University of Berlin voted in 1969 for statutes to ensure that all members of the institute-professors, lecturers and assistants (Mittelbau), students, and nonacademic staff members (e.g., secretaries)-were included in the process of decision making. In 1970 the Psychological Institute joined the faculty (Fachbereich) of philosophy and social sciences, emphasizing the social-critical intentions of the institute. For traditional psychologists at the Psychological Institute these democratically derived decisions led to discomfort and finally to initiatives that brought about a second Institute of Psychology at the Free University in 1970.

In the context of this politically motivated establishment of a second institute, Holzkamp was faced with an onslaught of personal attacks and had to learn to cope with the experience of public denunciation. His name appeared in the "scandal" of the so-called Schülerladen Rote Freiheit (untranslatable, literally meaning "pupils" shop red freedom") on national television, in newspapers, and in magazines, and he was held accountable for an alleged misuse of psychological practice (see Autorenkollektiv am Psychologischen Institut der Freien Universitt Berlin, 1971). He was, for financial reasons, formally responsible for a project of students who at that time were authorized to perform autonomous research. The project involved work with schoolchildren from Kreuzberg, an impoverished district in West Berlin; it was developed in the Zeitgeist of emancipatory educational means and goals. However, the project was not successful and was thus terminated. Yet, some time after the termination of the project, the German mass media started a campaign against Holzkamp (Haug, 1971), publishing stolen minutes in which children's sexual and coarse statements were recorded. The association of children and sexuality, and the alleged political manipulation of the children by Marxists, were topics that captured the interest of the population. Holzkamp survived the campaign and was not removed from the university as some politicians had demanded (see also Holzkamp, 1970, 1972a). However, the campaign gave legitimacy to the establishment of a second "traditional" institute of psychology in the faculty of education.

These personal experiences, the establishment of an Institute for Psychology separated from the critical Psychological Institute at the same university, the intellectual radicalization of some parts of the left, and the dynamics at the institute, moved Holzkamp away from compromises with traditional psychology. He (Holzkamp, 1972a) completely challenged his own writings from a socialist, classical Marxist position. ${ }^{8} \mathrm{He}$ criticized his own systematization (types of relevance) as being unfounded and rejected an instrumentalist reduction of science (relevance). With his socialist turn he acquired and applied principles of the cultural-historical school (Leontjew, 1973; see Holzkamp \& Schurig, 1973) and embraced the classical Marxist literature (Marx, Engels, Lenin). He sought to realize positive knowledge, which could not be produced by mere critique but only by research on the real objects of psychology.

$\mathrm{CP}$ at that time was very popular among students. An important dimension, often neglected when reconstructing theory development but especially important when dealing with approaches that emphasize emancipation, is the utopian notion

${ }^{8}$ This type of self-criticism is well-known in the political Marxism of former existing socialist states. 
that Holzkamp provided, and which gave hope (rise) and later despair (decline) to generations of critical psychology students in Germany. Students and practicing psychologists were disenchanted with traditional psychology, and Holzkamp, arriving from mainstream psychology himself, provided convincing and sophisticated arguments that were used as powerful tools to express deep-seated discomforts with psychology. CP also offered a utopia for a better psychology, embedded in a better society. Although his main focus was psychology and not politics, Holzkamp (1972a) exercised such revolutionary rhetoric: "For socialists at universities, liberation of the individual must mean insight into the necessity of long-term, burdensome, and disciplined work under the goals of scientific socialism" (p. 236). It is evident that socialism meant something positive, something that would bring exploitation to an end, and something that would allow individuals to use their talents and fulfill their needs. Thus, Marxists at universities must fight for a "socialist science" (Holzkamp, 1972a, p. 269). ${ }^{9}$

\section{Critical-Conceptual Period}

In the critical-conceptual period (1973-1983), Holzkamp held that psychology's problems could not be solved within the framework of traditional psychology, or in compromise between critical and mainstream thinking, but rather that psychology requires a radically different outlook. Thus, he and his colleagues attempted to develop a better conceptualization of psychological objects.

The first book within this new framework dealt with the reconstruction of the object of perception. The book Sensory Knowledge (Holzkamp, 1973) laid out the basic methodology for conceptual studies in German CP. Holzkamp argued that a real understanding of perception in general psychology would be possible only by including the natural history, the prehistory, and the history of humanity. Accordingly, he suggested three steps in analyzing psychological concepts such as perception. In the first step, one must incorporate the natural history of perception and identify the general evolutionary-biological characteristics of perception. In the second step, one must analyze the main features of perception with regard to their general societal-historical characteristics by focusing on the transition from prehuman to human life forms. In the third step, one must clarify perception under a given historical-economic reality such as bourgeois society. To accomplish these goals for psychology, CP must include material from biology, physiology, ethology, anthropology, archaeology, and so on. Holzkamp (1973) emphasized that Darwin's theory of evolution is the decisive framework for natural-historical analyses.

On the basis of this general methodology, colleagues at the Psychological Institute followed with their own studies of psychological objects. Especially important were the works of Holzkamp-Osterkamp $(1975,1976)^{10}$ on emotion and

${ }^{9}$ It would also be interesting to reconstruct the development of critical psychologies from a German anti-American point of view. AStA (1967), for example, compared the United States' involvement in Vietnam with crimes of Nazi Germany (p. 7). The critique of American psychology was nourished by the shortcomings of American politics (e.g., the Vietnam war) and also by national hurts, because German psychology, once a strong and powerful branch of international psychology, was no longer influential.

${ }^{10}$ Interesting, from a psychology-of-science perspective, is the fact that a second significant figure in CP's program is Holzkamp's wife, Ute Osterkamp. Another work emerging from the 
motivation, and the works of the trained biologist Schurig on the natural history of the psyche and the consciousness (e.g., Schurig, 1976). The many books produced by the Psychological Institute indicate that CP was the result of a scientific community working together on a common research program, refining methods and enriching the knowledge base of CP. It was, however, Holzkamp who summarized and elaborated the results in 1983 with his voluminous study Foundation of Psychology (Holzkamp, 1983). In this book, he intended not only to reconstruct psychological objects but also to reconstruct the psyche as such. Using a so-called analysis of categories, he intended to provide a systematicparadigmatic foundation for psychology, its subject matter, and methodology.

In the critical-conceptual period, Holzkamp (1977/1978b) also refined his critique of psychology. This critique was an important part of a process in which the clarification of the conceptual foundations of psychology was perceived as linked to the critique of traditional psychology. Traditional psychology was now depicted as producing small and isolated empirical results while lacking theoretical unification. The status quo of psychology was described as an accumulation and proliferation of competing theories, based on different models of human nature, different methods, and different practices, and its history was characterized as a series of theoretical fads. The accumulation of statistically significant yet theoretically insignificant findings was perceived as leading to the stagnation of knowledge and to the lack of scientific progress in psychology.

As an alternative, Holzkamp (1983) suggested a unified paradigm for psychology to overcome the indeterminacy of psychology, a topic that can be identified in all of his periods (Teo, 1993). In the precritical works, for example, Holzkamp (1964) challenged operational definitions in psychology as leading to the inflation of definitions in psychology, or he argued that causality is constructed arbitrarily by the experimenter (Holzkamp, 1968). In the critical-conceptual period, the circularity of empirical research was considered a major example of the indeterminacy of psychology (Holzkamp, 1974/1978a, p. 144). Essentially, he argued that any conceptualization leads to results within the conceptualization, whereas the conceptualization itself cannot be tested empirically (the conceptualization is a presupposition). Therefore, psychology presents contradictory theories regarding the same object, whereas all theories are empirically tested and "proven." "Consequently, psychology requires clarification of its basic concepts, which could be achieved through a foundation of psychology (Holzkamp, 1983).

The "permanent crisis" (Holzkamp, 1983, p. 45) of mainstream psychology was thus attributed not to the theory-practice problem or to simple ideology but to the indeterminate status of basic concepts (categories). A real crisis intervention program, according to Holzkamp's analysis, must tackle the real source of the crisis-the subject matter of psychology - and must develop scientifically qualified categories that adequately grasp the subject matter of psychology. Thus, only after psychology develops an adequate understanding of its subject matter does it

Psychological Institute, significant for a critical history of psychology, yet not written in the framework of CP, was presented by Jaeger and Staeuble (1978).

${ }^{1}$ Later, Holzkamp used the notion of pseudoempiricism by elaborating on the argument that psychology confuses reasons with causes (Holzkamp, 1986/1987). He argued that in several important psychological studies if-then statements have an implicate character, and thus empirical hypothesis testing is not a test but rather an application of good reasons. 
make sense to talk about adequate methodologies. In this context he criticized traditional psychology for using an investigative practice that conceptualizes the subject matter according to the way the method prescribes it, an approach in which the method dominates the problem, or problems are chosen in subordination of method (Holzkamp, 1983).

Holzkamp's alternative, a system model of psychology, pursued a different logic. According to the present status of knowledge, one must assume that humans are the result of a long evolutionary process. At the evolutionary beginning stood very simple organisms that differentiated into more complex organisms over time. Holzkamp suggested that it also made sense to assume that our psychology (psyche) is part of the same evolutionary process. Why should it not be possible to reconstruct the development of the psyche? To achieve that, he suggested an analysis of categories, which is based on a historical-empirical method (Holzkamp, 1983). With this method he reconstructed the development of the psyche to its human level. Using so-called preconcepts, and following the evolutionary development of the psyche, its differentiation, and qualifications on different levels, a system of categories (basic concepts) was developed by matching processes and categories. According to Holzkamp, real processes and categories correspond with each other; thus, it is possible to conceptualize the real subject matter of psychology.

Holzkamp identified, for example, qualitative transitions in the development of the psyche: the transition from prepsychical to psychical organisms, the differentiation of special functions and dimensions, the evolution of the capacity for learning and individual development, and the emergence of the societal nature of human beings. The difference between Holzkamp and traditional Darwinism is based on the Marxist understanding that at a certain point in evolutionary development natural history was superceded (not abolished) by a societalhistorical development that allowed a new quality of development. Applying these ideas, he was able to derive general definitions of human subjectivity and their meaning within bourgeois societies (cf. Tolman \& Maiers, 1991).

For example, to analyze human activities in bourgeois societies, Holzkamp (1983) developed the category pair generalized action potence versus restrictive action potence. An analysis of restrictive action potence seemed to him more important as it is the typical coping pattern of individuals in bourgeois societies. Restrictive action potence refers, for example, to an instrumentality in human relationships, to an arrangement with the powerful, to actions in which human beings give up long-term goals to achieve short-term advantages, or to actions that lead to alienation. Thinking within restrictive action potence is static and isolating, and emotions are characterized by anxiety and inner compulsions. As an alternative, he suggested a generalized action potence that calls for "liberated" actions. The category pair was developed not to put individuals into a certain category but to enlighten humans about their own potencies, which already refers to the idea of psychology as the science of the subject (see below).

In the 1970 s, CP reached its peak. During these years, critical psychologists not only published a number of influential books and articles, but they also organized huge conferences that were also attended by traditional psychologists who considered it necessary to be informed about the development and knowledge production of CP. A highlight was the first congress of CP in Marburg in 1977, for 
which Braun and Holzkamp (1977) reported 3,000 participants, a huge number for that time and for a psychology conference in Germany. ${ }^{12}$

\section{Critical-Conceptual Period: Problems}

In the 1980s it became evident-even to many leftists-that the land of socialism would not appear. Capitalism seemed to be more or less thriving, ${ }^{13}$ and those countries committed to Marxism, socialism, and communism were in crisis. For the political changes in Europe and North America since the early 1980s, names such as Thatcher, Reagan, and Kohl may stand as simplified icons. The final breakdown of socialist countries, and the authentic reports of people from socialist countries who had been sympathetic to socialism, discredited Marxism as a lived experience. ${ }^{14}$

Similar to political-economic Marxists, critical psychologists implicitly assumed that mainstream psychology would disappear once capitalism disappeared, once psychologists realized that there are alternatives to mainstream psychology, and once people recognized that traditional psychology is trivial, biased, arbitrary, and of little significance for the majority of people (see Holzkamp, 1983). Yet mainstream psychology also flourished, as the increase in journal articles, conference attendance, and student enrollments at universities in Europe and North America showed. ${ }^{15}$

German CP, like other radical approaches at universities, was damaged institutionally by unfavorable hiring policies for the Psychological Institute that limited its development and by the fact that critical psychologists were rarely hired at other academic or research institutions. A look at the history of the Psychological Institute provides insight about processes of external mutilation to the development of theory (see Mattes, 1988).

A look at critical discourses in the 1980s indicates a shift away from Marxism toward diverse variants of postmodernism, starting in France, and toward the arguments of feminism and multiculturalism in North America (see Teo, 1997). In postmodern discourse the very idea of a grand theory, or the possibility of a global, universal, and inclusive theory-exactly what Holzkamp attempted with a foundation of psychology-was challenged vehemently. Postmodern discourse, with its rejection of large projects, its departure from meta-narratives, and its affirmation of multiplicity, plurality, difference, antifoundationalism, and local truths (see Teo, 1996), hit at the very heart of CP. For many critical communities postmodern relativism seemed more attractive than the search for a unified, reality-representing system of categories.

Thus, Foundation of Psychology (Holzkamp, 1983), which concluded the critical-conceptual period, was subject to many criticisms. The book no longer

\footnotetext{
${ }^{12}$ In comparison, for the congress in 1994 in Hamburg the Deutsche Gesellschaft fuir Psychologie (German Society for Psychology) reported 2,000 participants (Pawlik, 1995, p. 3).

${ }^{13}$ Excluding moral criteria.

${ }^{14}$ Holzkamp (1991c) dealt with issues of German unification.

${ }^{15}$ As some have observed, many students seem to not want to acquire critical knowledge anymore but rather to learn technologies that are applicable or marketable. A detailed look at the impact of this shift in orientation can also be found in different areas of psychology. For example, in developmental psychology one might find a move from socialization toward biological explanations of development.
} 
presented a social utopia as such. The implicit utopia was embedded within a Marxist-Leninist concept of societal development with communism at its end, but this utopia was no longer convincing. The book was extremely difficult to understand because of its system of peculiar terms. Students of psychology were frustrated by its complexity, practitioners asked for its practical implications, traditional psychologists wondered about its significance for empirical research, and other critical psychologists were disappointed by its presumptuous character, as Holzkamp (1983) intended to place the "whole of psychology" on a "new scientific basis" (p. 19). ${ }^{16}$

In fact, the highly sophisticated theoretical discussions on the permanent crisis of traditional psychology did not find acceptance within the scientific community, nor did it hurt traditional psychology. Some of the critiques of this period, and even the critiques from the critical-emancipatory period, could also be held against CP. It is not difficult to find "ideological" statements in CP's framework. For example, in his book on the foundation of psychology, Holzkamp (1983) emphasized the unity of Marx, Engels, and Lenin and set his position off clearly against Marxists who "deny Lenin's contribution to the further development of Marxist theory" (p. 33). Such a statement was directed against other Marxists and must have been difficult for traditional psychologists to understand. Already in the 1970s discussions were increasingly aimed toward criticizing other critical psychologists (e.g., Holzkamp, 1974/1978a). Critical psychologists of different frameworks were not able to establish a working communication among each other, a situation that probably resulted from Holzkamp's system model of psychology and that reflects a phenomenon typical of communities in crisis.

The elaborate discussions no longer attracted a wider social movement. CP became more academic and provided no immediate solutions, techniques, or applications to attract practitioners; indeed, the development of a critical psychological code in an analysis of categories seemed awkward to practitioners. Most damaging, from a practical point of view, was CP's perceived irrelevance or lack of practice. ${ }^{17}$ As positions for critical psychologists were (and are) rare in academia, and as most graduates from the Psychological Institute went into practice, CP would have needed intense support from practitioners for its survival. But as it was difficult to derive immediate practices from critical studies, many critical psychologists went into traditional paths, such as therapy or counseling. Amalgamations with psychoanalysis, humanistic approaches, and diverse therapy schools grew (see Rexilius, 1988).

From an epistemological point of view, Holzkamp (1983) provided a brilliant reconstruction of the psyche. But in examining the historical-empirical method of CP, it becomes evident that this method is confronted with the same problems with which every empirical research program is plagued. The dominance of theory applies to his approach, too. Holzkamp (1983) was fair in saying that his approach and his categories were based in the classical Marxist tradition, for which labor (in its Marxist meaning) is central to an understanding of the self-constitution of

\footnotetext{
${ }^{16}$ These statements are based on personal communications with critical psychologists during my involvement in the Austrian Society for Critical Psychology.

${ }^{17} \mathrm{CP}$ cared about practice, as is reflected, for example, in the institutionalized "TheoryPractice" project. Yet the project's publications were abstract and did not provide immediate technologies that would make CP attractive to a market of practitioners.
} 
humankind. But if one were to emphasize the category of interaction, as Habermas (1976/1979) did, the reconstruction would be rather different. Holzkamp, too, was not able to transcend the dominance of theory (cf. Teo, 1995).

A systematic-foundational program for solving the subject matter of psychology is convincing only if one accepts the premises of CP. Nevertheless, Holzkamp thought that $\mathrm{CP}$ was the first to bring a real paradigm à la Kuhn into psychology (Holzkamp, 1983). Obviously, the term scientific revolution does not fit with CP, because the term implies success within the scientific community. CP, more modestly, might be considered a German scientific contribution to international psychology. In my view, $\mathrm{CP}$, like most psychological frameworks, lacks a self-reflective attitude, one that allows for an understanding of CP as part of a cultural, historical, and social context. Such a self-critical attitude is essential for any critical approach and helps to avoid cultlike practices.

Even for a positively disposed observer, the many turns of Holzkamp might have been irritating. His philosophy of science, for example, in the precritical period is very different from the critical-emancipatory and critical-conceptual ones. One can interpret his many theoretical shifts as an indication of his theoretical openness, as reflecting a dedication to an object of investigation, or as representing the courage to alter a position on the basis of more developed understandings. Yet the shifts make it difficult to accept a supposed foundation at a certain period as the real foundation. A reader might also have some cynical doubts: How is it possible to unite mainstream psychology with its many branches when it is not possible to unify the small group and few frameworks of German critical psychologies?

\section{Subject-Scientific Period}

From 1983 to 1995 Holzkamp tried to demonstrate the significance of his analyses for psychology by elaborating on the idea of a science of the subject (see also Holzkamp, 1992), as already suggested in Foundation of Psychology. In addition, he tried to do justice to the cultural emphasis on the self by acknowledging the contributions of psychoanalysis (Holzkamp, 1984/1991b) and phenomenology (Holzkamp, 1984b) to CP's development. The utopian dimension of CP in this latest phase is very modest. Psychology from the standpoint of the subject should help individuals to understand their possibilities and to improve their quality of life under bourgeois life conditions. Concepts developed within the framework of CP should help to fulfill these goals. In further development of this idea, he published his final monograph, Learning: Subject-Scientific Foundation (Holzkamp, 1993), in which a learning theory from the standpoint of the subject was presented.

$\mathrm{CP}$ as a subject-oriented research program promotes a type of research in which subjects are both participants and co-researchers simultaneously (Holzkamp, 1986, 1985/1991a). Psychological research is intended as research for people and not about people. This is possible only if psychological research is conducted from the standpoint of the subject. The perspective of the subject is meant in its widest sense. In an interview, Holzkamp (1984a) argued, using the example of an alcoholic, that if a researcher or therapist already knows at the beginning of an intervention that drinking must end, subjectivity, the subject's standpoint, is 
excluded. It might turn out, after a thorough analysis of the person's situation, that drinking alcohol is the best solution for this specific person.

\section{Consequences}

Are there any lessons to be learned for an Anglo-American readership? I think the answer is yes. First of all, there are significant psychological developments outside of North America that should not be disregarded. CP has elaborated many theoretical insights that are worth following, and CP has provided interesting criticisms that show plainly some of the deficits of mainstream psychology. Too, the idea of performing a psychology from the perspective of the subject, as Holzkamp derived it, is innovative and should be explored further.

Among the many interesting topics, one issue that might be of interest to historians and theorists of psychology stands out. Danziger (1997) recently challenged psychology's categories for being intended as natural kinds but as having meaning only in an historical and social context. Danziger's historical analysis of categories is one side of a coin, the other side of which is the attempt to construct concepts or theories that grasp parts of human subjectivity more adequately. If the limits of my categories are the limits of my world (paraphrasing Wittgenstein, 1968), how might better categories than those provided by traditional psychology be conceptualized? The development of solutions to this problem remains an important task for theoretical or philosophical psychologists.

Holzkamp has also inspired work on critical topics such as liberation. In my own work, I have suggested (Teo, in press) that an elaboration of categories is not possible within a rigid system or systematic foundation but is possible only within a conceptual network that works, to use a metaphor, like a rhizome, as described by Deleuze and Guattari (1987). Basic categories such as labor (Holzkamp) must be supplemented by interaction (Habermas, 1976/1979), by an aesthetical dimension (Foucault, 1986), or by other concepts that allow for the concrete practice of liberation. ${ }^{18}$

For an international program of critical psychology I would suggest beginning with the idea that human subjectivity must be contextualized and historized. This also means that the subjectivity of the researcher or research community, and therefore theories, must be understood as part of a cultural-historical context. Critical studies of psychology require a network of concepts that are able to deal with the contributions of critical thought, represented, for example, in the multiple-voices discourses (e.g., feminism and antiracism). This network must include experiences and thoughts of non-EuroAmerican sociocultural communities, as critical studies in psychology require an openness to diversity in critical thinking (on allowing different critical voices; see Fox \& Prilleltensky, 1997; Parker \& Spears, 1996). Nevertheless, Klaus Holzkamp remains a classical giant of psychology, one who has provided significant insights that are relevant for understanding contemporary psychology and one who encourages psychologists to look further.

\footnotetext{
${ }^{18}$ Foucault (1976) suggested a pragmatic usage for classical theories by using Marx's concepts and ideas without falling into the trap of submitting himself to the system.
} 


\section{References}

AStA. (Ed.). (1967). Von der freien zur kritischen Universität. Geschichte der Krise an der Freien Universität Berlin (2. völlig überarbeitete Auflage) [From the free to the critical university: History of the crisis at the Free University of Berlin]. Berlin, Germany: AStA der Freien Universität Berlin.

Autorenkollektiv am Psychologischen Institut der Freien Universität Berlin. (1971). Sozialistische Projektarbeit im Berliner Schülerladen Rote Freiheit [Socialist projectwork in the Berliner Schülerladen Rote Freiheit]. Frankfurt, Germany: Fischer.

Benz, W. (Ed.). (1989). Die Geschichte der Bundesrepublik Deutschland (4 Bände) [History of the Federal Republic of Germany]. Frankfurt, Germany: Fischer.

Braun, K.-H., \& Holzkamp, K. (1977). Vorbemerkung [Preface]. In K.-H. Braun \& K. Holzkamp (Eds.), Bericht über den I. Kongress Kritische Psychologie in Marburg vom 13, bis 15, Mai 1977 (pp. 11-12). Cologne, Germany: Pahl-Rugenstein.

Danziger, K. (1997). Naming the mind: How psychology found its language. London: Sage.

Deleuze, G., \& Guattari, F. (1987). A thousand plateaus: Capitalism and schizophrenia (B. Massumi, Trans.). Minneapolis: University of Minnesota Press.

Fancher, R. E. (1996). Pioneers of psychology (3rd ed.). New York: Norton.

Foucault, M. (1976). Mikrophysik der Macht. Über Strafjustiz, Psychiatrie und Medizin [Microphysics of power: Criminal justice, psychiatry, and medicine]. Berlin, Germany: Merve.

Foucault, M. (1986). The care of the self: Volume 3 of the history of sexuality (R. Hurley, Trans.). New York: Vintage Books. (Original work published 1984)

Fox, D., \& Prilleltensky, I. (Eds.). (1997). Critical psychology: An introduction. London: Sage.

Habermas, J. (1979). Communication and the evolution of society (T. McCarthy, Trans.). Boston: Beacon. (Original work published 1976)

Haug, W. F. (1971). Der sexuell-politische Skandal als Instrument antidemokratischer Kampagnen [The sexual-political scandal as an instrument for anti-democratic campaign]. In Autorenkollektiv am Psychologischen Institut der Freien Universität Berlin (Ed.), Sozialistische Projektarbeit im Berliner Schülerladen Rote Freiheit (pp. 389-464). Frankfurt, Germany: Fischer.

Holzkamp, K. (1964). Theorie und Experiment in der Psychologie: Eine grundlagenkritische Untersuchung [Theory and experiment in psychology: A foundation-critical study]. Berlin, Germany: De Gruyter.

Holzkamp, K. (1968). Wissenschaft als Handlung: Versuch einer neuen Grundlegung der Wissenschaftslehre [Science as action: Essay on a new foundation of the philosophy of science]. Berlin, Germany: De Gruyter.

Holzkamp, K. (1970). Interview zum Schülerladen [Interview on the pupils' shop]. Der Spiegel, 16, 99-102.

Holzkamp, K. (1972a). Die Beziehung zwischen gesellschaftlicher Relevanz und wissenschaftlichem Erkenntnisgehalt psychologischer Forschung (Kritisch-historische Analyse der vorstehenden Aufsätze) [The relationship between social relevance and the scientific epistemological content of psychological research (Critical-historical analysis of the preceding contributions)]. In K. Holzkamp, Kritische Psychologie: Vorbereitende Arbeiten (pp. 207-293). Frankfurt, Germany: Fischer.

Holzkamp, K. (1972b). Kritische Psychologie: Vorbereitende Arbeiten [Critical psychology: Preparatory works]. Frankfurt, Germany: Fischer.

Holzkamp, K. (1972c). Verborgene anthropologische Voraussetzungen der allgemeinen Psychologie [Hidden anthropological assumptions of general psychology]. In $\mathrm{K}$. Holzkamp, Kritische Psychologie: Vorbereitende Arbeiten (pp. 35-74). Frankfurt, Germany: Fischer. 
Holzkamp, K. (1972d). Wissenschaftstheoretische Voraussetzungen kritisch-emanzipatorischer Psychologie [Epistemological preconditions of critical-emancipatory psychology]. In K. Holzkamp, Kritische Psychologie: Vorbereitende Arbeiten (pp. 75-146). Frankfurt, Germany: Fischer. (Original work published 1970)

Holzkamp, K. (1972e). Zum Problem der Relevanz psychologischer Forschung für die Praxis [The problem of the relevance of psychological research for practice]. In K. Holzkamp, Kritische Psychologie: Vorbereitende Arbeiten (pp. 9-34). Frankfurt, Germany: Fischer. (Original work published 1970)

Holzkamp, K. (1973). Sinnliche Erkenntnis: Historischer Ursprung und gesellschaftliche Funktion der Wahrnehmung [Sensory knowledge: Historical origin and societal function of perception]. Frankfurt, Germany: Athenäum.

Holzkamp, K. (1978a). Die historische Methode des wissenschaftlichen Sozialismus und ihre Verkennung durch J. Bischoff [The historical method of scientific socialism and its misunderstanding by J. Bischoff]. In K. Holzkamp, Gesellschaftlichkeit des Individuums: Aufsätze 1974-1977 (pp. 41-128). Cologne, Germany: Pahl-Rugenstein. (Original work published 1974)

Holzkamp, K. (1978b). Die Überwindung der wissenschaftlichen Beliebigkeit psychologischer Theorien durch die Kritische Psychologie [Overcoming the scientific indeterminacy of psychological theories by critical psychology]. In K. Holzkamp, Gesellschaftlichkeit des Individuums: Aufsätze 1974-1977 (pp. 129-201). Cologne, Germany: Pahl-Rugenstein. (Original work published 1977)

Holzkamp, K. (1981). Theorie und Experiment in der Psychologie: Eine grundlagenkritische Untersuchung (Zweite, um ein Nachwort erweiterte Auflage) [Theory and experiment in psychology: A foundation-critical study (2nd edition with an epilogue)]. Berlin, Germany: De Gruyter. (Original work published 1964)

Holzkamp, K. (1983). Grundlegung der Psychologie [Foundation of psychology]. Frankfurt, Germany: Campus.

Holzkamp, K. (1984a). Die Menschen sitzen nicht im Kapitalismus wie in einem Käfig [Humans are not trapped in capitalism as in a cage]. Psychologie Heute, 11, 29-37.

Holzkamp, K. (1984b). Kritische Psychologie und phänomenologische Psychologie: Der Weg der Kritischen Psychologie zur Subjektwissenschaft [Critical psychology and phenomenological psychology: The track to the subject-science]. Forum Kritische Psychologie, 14, 5-55.

Holzkamp, K. (1986). "Wirkung" oder Erfahrung der Arbeitslosigkeit? Widersprüche und Perspektiven psychologischer Arbeitslosenforschung [Effects or experience of unemployment? Contradictions and perspectives of psychological research on unemployment]. Forum Kritische Psychologie, 18, 9-37.

Holzkamp, K. (1987). Die Verkennung von Handlungsbegründungen als empirische Zusammenhangsannahmen in sozialpsychologischen Theorien [The misunderstanding of action reasons as empirical propositions in social-psychological theories]. Forum Kritische Psychologie, 19, 23-58. (Original work published 1986)

Holzkamp, K. (1988). Die Entwicklung der Kritischen Psychologie zur Subjektwissenschaft [Development of critical psychology to a science of the subject]. In G. Rexilius (Ed.), Psychologie als Gesellschaftswissenschaft (pp. 298-317). Opladen, Germany: Westdeutscher Verlag.

Holzkamp, K. (1991a). Experience of self and scientific abjectivity. In C. W. Tolman \& W. Maiers (Eds.), Critical psychology: Contributions to an historical science of the subject (pp. 65-80). Cambridge, England: Cambridge University Press. (Original work published 1985)

Holzkamp, K. (1991b). Psychoanalysis and Marxist psychology. In C. W. Tolman \& W. Maiers (Eds.), Critical psychology: Contributions to an historical science of the subject (pp. 81-101). Cambridge, England: Cambridge University Press. (Original work published 1984) 
Holzkamp, K. (1991c). Zum Thema "Wendehälse" [On the topic of "Wendehälse"]. Forum Kritische Psychologie, 27, 74-77.

Holzkamp, K. (1992). On doing psychology critically. Theory and Psychology, 2, 193-204.

Holzkamp, K. (1993). Lernen: Subjektwissenschaftliche Grundlegung [Learning: Subjectscientific foundation]. Frankfurt, Germany: Campus.

Holzkamp, K., \& Keiler, P. (1967). Seriale und dimensionale Bedingungen des Lernens der Größenakzentuierung: Eine experimentelle Studie zur sozialen Wahrnehmung [Serial and dimensional conditions for learning size judgment: An experimental study on social perception]. Zeitschrift für experimentelle und angewandte Psychologie, 14, $407-441$.

Holzkamp, K., \& Schurig, V. (1973). Zur Einführung in A. N. Leontjews "Probleme der Entwicklung des Psychischen" [Introduction to A. N. Leontjew's "Problems of the development of the psyche]. In A. N. Leontjew, Probleme der Entwicklung des Psychischen (pp. XI-LII). Frankfurt, Germany: Athenäum-Verlag.

Holzkamp-Osterkamp, U. (1975). Grundlagen der psychologischen Motivationsforschung $l$ [Bases of psychological motivation research 1]. Frankfurt, Germany: Campus.

Holzkamp-Osterkamp, U. (1976). Grundlagen der psychologischen Motivationsforschung 2: Die Besonderheit menschlicher Bedürfnisse. Problematik und Erkenntnisgehalt der Psychoanalyse [Bases of psychological motivation research 2: The specificity of the human needs. Problems and knowledge content of psychoanalysis]. Frankfurt, Germany: Campus.

Jaeger, S., \& Osterkamp, U. (1987). Verzeichnis der Schriften Klaus Holzkamps [List of Klaus Holzkamp's works]. In W. Maiers \& M. Markard (Eds.), Kritische Psychologie als Subjektwissenschaft: Klaus Holzkamp zum 60. Geburtstag (pp. 241-251). Frankfurt, Germany: Campus.

Jaeger, S., \& Staeuble, I. (1978). Die gesellschaftliche Genese der Psychologie [The societal genesis of psychology]. Frankfurt, Germany: Campus.

Keiler, P. (1987). Bevor die Kritische Psychologie da war, war die Kritische Psychologie da [Before critical psychology was critical psychology]. In W. Maiers \& M. Markard (Eds.), Kritische Psychologie als Subjektwissenschaft: Klaus Holzkamp zum 60. Geburtstag (pp. 120-127). Frankfurt, Germany: Campus.

Kuhn, T. S. (1962). The structure of scientific revolutions. Chicago: University of Chicago Press.

Leontjew, A. N. (1973). Probleme der Entwicklung des Psychischen. [Problems of the development of the psyche]. Frankfurt, Germany: Athenäum. (Original work published 1959)

Maiers, W. (1991). Critical psychology: Historical background and task. In C. W. Tolman \& W. Maiers (Eds.), Critical psychology: Contributions to an historical science of the subject (pp. 23-49). Cambridge, England: Cambridge University Press.

Maiers, W., \& Markard, M. (1987). Der Beitrag der Kritischen Psychologie zur Erkennbarkeit und Emanzipation menschlicher Subjektivität [Contribution of critical psychology for the recognizability and emancipation of human subjectivity]. In W. Maiers \& M. Markard (Eds.), Kritische Psychologie als Subjektwissenschaft: Klaus Holzkamp zum 60. Geburtstag (pp. 9-30). Frankfurt, Germany: Campus.

Mattes, P. (1985). Die Psychologiekritik der Studentenbewegung [The critique of psychology of the student movement]. In M. G. Ash \& U. Geuter (Eds.), Geschichte der deutschen Psychologie im 20. Jahrhundert (pp. 286-313). Opladen, Germany: Westdeutscher Verlag.

Mattes, P. (1988). Das PI in Berlin-Wissenschaftskritik und Institution. Zur Geschichte eines psychologischen Instituts [The PI in Berlin - Critique of science and institution: History of a psychological institute]. In G. Rexilius (Ed.), Psychologie als Gesellschaftswissenschaft (pp. 28-61). Opladen, Germany: Westdeutscher Verlag.

Métraux, A. (1985). Der Methodenstreit und die Amerikanisierung der Psychologie in der 
Bundesrepublik 1950-1970 [The dispute about method and the Americanization of psychology in the Federal Republic of Germany, 1950-1970]. In M. G. Ash \& U. Geuter (Eds.), Geschichte der deutschen Psychologie im 20. Jahrhundert (pp. 225-251). Opladen, Germany: Westdeutscher Verlag.

Morawski, J. G. (1982). Assessing psychology's moral heritage through our neglected utopias. American Psychologist, 37, 1082-1095.

Parker, I., \& Spears, R. (Eds.). (1996). Psychology and society: Radical theory and practice. London: Pluto.

Pawlik, K. (1995). Begrüssung [Welcome]. In K. Pawlik (Ed.), Bericht über den 39. Kongress der Deutschen Gesellschaft für Psychologie in Hamburg 1994 (pp. 3-4). Göttingen, Germany: Hogrefe.

Rabehl, B. (1988). Am Ende der Utopie: Die politische Geschichte der Freien Universität Berlin [The end of a utopia: Political history of the Free University of Berlin]. Berlin, Germany: Argon.

Rexilius, G. (1987). Subjektwissenschaft und russische Revolution oder: Der heimliche Konservatismus der Kritischen Psychologie [Subject science and the Russian revolution or: The implicit conservatism of critical psychology]. In W. Maiers \& $\mathbf{M}$. Markard (Eds.), Kritische Psychologie als Subjektwissenschaft. Klaus Holzkamp zum 60. Geburtstag (pp. 163-176). Frankfurt, Germany: Campus.

Rexilius, G. (Ed.). (1988). Psychologie als Gesellschaftswissenschaft: Geschichte, Theorie und Praxis kritischer Psychologie [Psychology as a social science: History, theory, and practice of critical psychology]. Opladen, Germany: Westdeutscher Verlag.

Rexilius, G., \& Mattes, P. (1988). Kritische Psychologie: Die Entwicklung eines sozialwissenschaftlichen Paradigmas [Critical psychology: Development of a social scientific paradigm]. Störfaktor, 7/8, 6-23.

Schurig, V. (1976). Die Entstehung des Bewußtseins [The origin of consciousness]. Frankfurt, Germany: Campus.

Staeuble, I. (1985). "Subjektpsychologie" oder "subjektlose Psychologie:" Gesellschaftliche und institutionelle Bedingungen der Herausbildung der modernen Psychologie [Psychology with a subject or without a subject: Social and institutional factors for the emergence of modern psychology]. In M. G. Ash \& U. Geuter (Eds.), Geschichte der deutschen Psychologie im 20. Jahrhundert (pp. 19-44). Opladen, Germany: Westdeutscher Verlag.

Teo, T. (1993). Theoriendynamik in der Psychologie: Zur Rekonstruktion von Wissenschaftsentwicklung am Fallbeispiel von Klaus Holzkamp [Theory dynamics in psychology: The reconstruction of scientific development using Klaus Holzkamp as an example]. Hamburg, Germany: Argument.

Teo, T. (1995). Society, subject, and development: Analysis of categories in German critical thought. In I. Lubek, R. van Hezewijk, G. Pheterson, \& C. W. Tolman (Eds.), Trends and issues in theoretical psychology (pp. 353-358). New York: Springer.

Teo, T. (1996). Practical reason in psychology: Postmodern discourse and a neo-modern alternative. In C. W. Tolman, F. Cherry, R. v. Hezewijk, \& I. Lubek (Eds.), Problems of theoretical psychology (pp. 280-290). Toronto, Ontario, Canada: Captus.

Teo, T. (1997). Developmental psychology and the relevance of a critical metatheoretical reflection. Human Development, 40, 195-210.

Teo, T. (in press). Prolegomenon to a contemporary psychology of liberation. Theory \& Psychology.

Tolman, C. W. (1989). What's critical about Kritische Psychologie? Canadian Psychology, $30,628-635$.

Tolman, C. W. (1994). Psychology, society, and subjectivity: An introduction to German critical psychology. London: Routledge. 
Tolman, C. W., \& Maiers, W. (Ed.). (1991). Critical psychology: Contributions to an historical science of the subject. Cambridge, England: Cambridge University Press. van Ijzendoorn, M. H., \& van der Veer, R. (1984). Main currents of critical psychology: Vygotskij, Holzkamp, Riegel. New York: Irvington.

Wittgenstein, L. (1968). Philosophical investigations (G. E. M. Anscombe, Trans., 3rd ed.). Oxford, England: Basil Blackwell.

Received July 28, 1997

Revision received January 19, 1998

Accepted March 20, 1998 